\title{
Syntetiske cannabinoider - effekt og forekomst
}

\begin{abstract}
Sammendrag
Bakgrunn. «Spice» er betegnelsen på ulike produkter som inneholder syntetiske cannabinoider. I de senere år er det rapportert et økende antall slike produkter på det illegale markedet, også i Norge. Stoffene selges over Internett som «lovlig» cannabis. Flere av dem er etter hvert blitt narkotikaklassifisert, også her i landet, men stadig nye varianter utvikles. Vi gir her en oversikt over hva man i dag vet om forekomsten av syntetiske cannabinoider og deres effekter.
\end{abstract}

Kunnskapsgrunnlag. Oversikten er basert på et skjønnsmessig utvalg av relevante artikler etter litteratursøk i PubMed samt på rapporter fra norske og europeiske myndigheter og forskningsinstitusjoner.

Resultater. Syntetiske cannabinoider er en stor gruppe rusmidler som har liknende effekter som cannabis, men som kan være betydelig mer potente. Innholdet i ulike Spice-produkter varierer i potens, renhetsgrad og når det gjelder hvilke stoffer og antall stoffer som er tilsatt. Dette gir risiko for utilsiktet overdose. Fra utlandet er det rapportert om hjerteinfarkt hos tenåringer, alvorlige psykoser, angst, bevisstløshet og dødsfall etter bruk.

Fortolkning. Syntetiske cannabinoider markedsføres over Internett som lovlig og ufarlig cannabis, men inntak kan føre til alvorlig intoksikasjon og død. Det er et stort behov for mer kunnskap om virkninger og skadeeffekter av disse stoffene.

\section{Silja Skogstad Tuv}

situ@fhi.no

Maren Cecilie Strand

Ritva Karinen

Elisabeth Leere Øiestad

Asbjørg S. Christophersen

Vigdis Vindenes

Divisjon for rettsmedisin og rusmiddelforskning

Nasjonalt folkehelseinstitutt

Syntetiske cannabinoider (SC) er en stor gruppe rusmidler med cannabisliknende effekter. De kan være betydelig mer potente enn naturlig forekommende cannabinoider (1). Gjennom Internett-butikker har det vært solgt syntetiske cannabinoider under navnet Spice siden tidlig etter årtusenskiftet. Stoffene markedsføres som lovlige urteblandinger, blant annet som røkelse (2). Vanlige betegnelser er «herbal highs» og «legal highs», noe som indikerer at de både er naturlige og lovlige (1). Løsninger som inneholder syntetiske cannabinoider sprayes trolig på urteblandinger som i utgangspunktet ikke har noen psykoaktive egenskaper (2). Innholdet i de ulike Spice-produkter er svært variabelt, både når det gjelder hvilke og hvor mange stoffer som er tilsatt og også stoffenes renhetsgrad. Ulike kombinasjoner og varierende mengde i produktene medfører at brukere risikerer utilsiktede overdoseringer (3). Fra 21.12. 2011 har Statens legemiddelverk ført opp åtte syntetiske cannabinoider på den norske narkotikalisten (4).

Et økende antall syntetiske cannabinoider er blitt identifisert i ulike blandinger (5-7). I Norge er det gjort flere større beslag (8), og analyser gjort ved vårt institutt har påvist syntetiske cannabinoider i prøver fra bilførere og fra innsatte (egne, upubliserte data). I en undersøkelse med amerikanske collegestudenter rapporterte $8 \%$ at de hadde brukt minst ett syntetisk cannabinoid (9). Det foreligger ingen publiserte studier om hvor utbredt bruken er i Norge. Vi ønsker her å gi en oversikt over virkninger av og deteksjonsmetoder for disse nye og farlige rusmidlene.

\section{Kunnskapsgrunnlag}

Oversikten er basert på et skjønnsmessig utvalg av artikler etter litteratursøk i PubMed. Søkeord inkluderte «spice», «synthetic cannabinoids», «legal high» og «herbal high». Disse ble koblet sammen med «detection», «analysis», «pharmacology», «intoxication», «effects» og «clinical presentation». Kun engelskspråklige og norske artik- ler ble inkludert. Søket ble avsluttet 12.4. 2012. I tillegg inkluderte vi rapporter fra norske myndigheter og myndigheter i andre europeiske land.

\section{Gruppering av syntetiske cannabinoider}

$\Delta^{9}$-tetrahydrocannabinol (THC) er den viktigste psykoaktive substansen i cannabisprodukter som hasj og marihuana (10). Syntetisk fremstilt THC (dronabinol) brukes i noen grad i medisinsk behandling, blant annet i Danmark. Etter at THC ble isolert i 1960-årene, er en rekke syntetiske cannabinoidreseptoragonister blitt utviklet, hovedsakelig til smertebehandling (fig 1). Kun et fåtall av de syntetiske cannabinoidene brukes i medisinsk behandling (ett eksempel er nabilon), og verken THC eller syntetiske cannabinoider er tillatt markedsført i Norge. Dette er hovedsakelig fordi det har vært vanskelig å skille ønskede effekter fra uønskede psykoaktive effekter (11). Noen syntetiske cannabinoider er THC-analoger, men mange er også strukturelt forskjellig (fig 2).

Det finnes en rekke ulike inndelinger av de syntetiske cannabinoidene. I en av disse deles de inn i fire hovedgrupper (11):

- Klassiske cannabinoider er analoger av THC og er basert på en dibenzopyranring, f.eks. HU-210 (syntetisert ved Hebrew University) og nabilon (fig 2a)

- Ikke-klassiske cannabinoider (sykloheksylfenoler, CP), utviklet av Pfizer i 1970årene (fig 2b).

- JWH-substanser (aminoalkylindolene) er den største gruppen. De er oppkalt etter J.W. Huffman, som først syntetiserte disse forbindelsene i 1990-årene, f.eks. JWH-018 (fig 2c)

- Benzoylindoler, som AM-694, ofte halogenerte, syntetisert av Alexadros Makriyanni (fig 2d)

\section{Hovedbudskap}

- Syntetiske cannabinoider gir en cannabisliknende rus, men kan være betydelig mer potente enn cannabis

- Bruk av syntetiske cannabinoider har ført til alvorlige intoksikasjoner og dødsfall

- Det er et stort behov for mer kunnskap om virkninger og effekter ved bruk av disse rusmidlene 


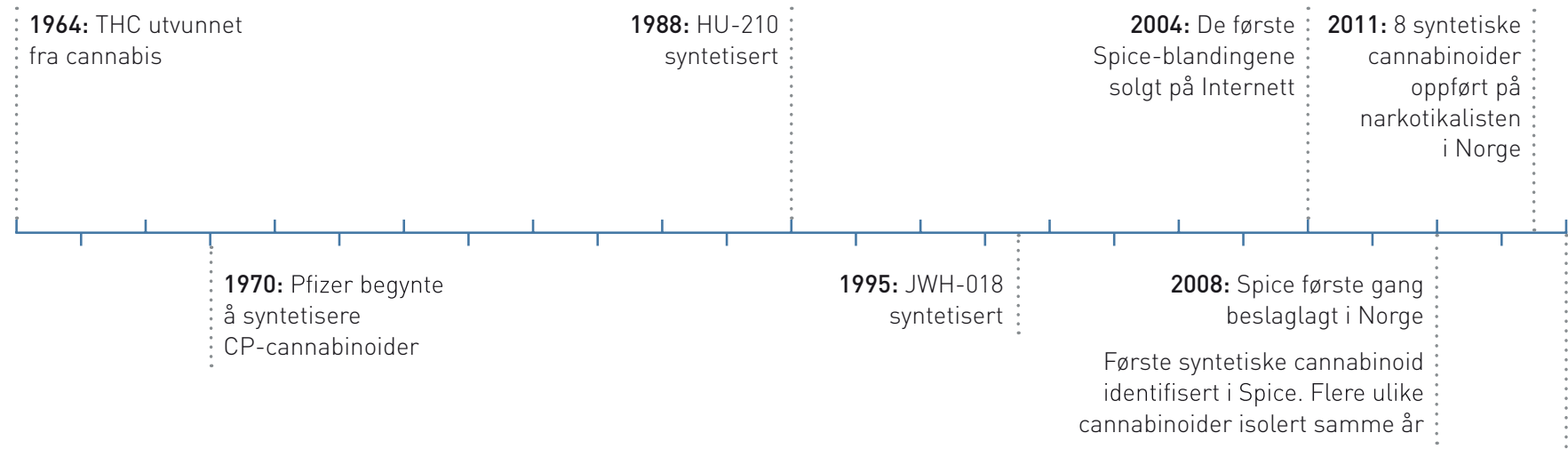

2012: Spice påvist i prøver fra norske bilførere

Figur 1 Tidslinje som viser utviklingen fra da tetrahydrocannabinol ble påvist til forbud mot nye syntetiske cannabinoider (THC $=\Delta^{9}$-tetrahydrocannabinol)<smiles>[R]c1cc(O)c2c(c1)OC(C)(C)C1CCC([R])CC21</smiles><smiles>[R]c1ccc(C2CC(O)CCC2[R])c(O)c1</smiles>

b<smiles>[R]c1ccc2c([R])ccc(C(=O)c3c([R])n([R])c4ccccc34)c2c1</smiles>

C<smiles>[R]c1ccc(C(=O)c2cn([R])c3ccccc23)c([R])c1</smiles>

Figur 2 De vanligste formene for syntetiske cannabinoider har en av følgende hovedstrukturer: al klassiske cannabinoider, b) sykloheksylfenoler, cl aminoalkylindoler, d) Benzoylindoler. Sidegruppene (R) kan variere

\section{Farmakokinetikk/farmakodynamikk og analytikk}

Syntetiske cannabinoider inntas vanligvis ved røyking, men inntak kan også skje ved inhalasjon eller peroralt (11). Det er begrenset kunnskap om absorpsjon, distribusjon, metabolisme og eliminasjon (12), men stoffene omdannes i betydelig grad av leverenzymer $(12,13)$. Noen av de syntetiske cannabinoidene kan ha lang halveringstid (1). Etter røyking oppnås toppkonsentrasjon av JWH-018 i blod etter omtrent fem minutter, og konsentrasjonen faller til under $10 \%$ i løpet av tre timer. JWH-018 er likevel påvisbart $\mathrm{i}$ inntil 24 timer i blod (13). JWH-018 er også påvist i spyttprøver i inntil 12 timer etter enkeltinntak, med en toppkonsentrasjon 20 minutter etter røyking (14).

Studier har vist at moderstoffet av syntetiske cannabinoider ikke nødvendigvis gjen- finnes i urinen etter et enkeltinntak (15), mens flere omdanningsprodukter skilles ut $\mathrm{i}$ høyere konsentrasjoner i urin (15-17). Det er også funnet syntetiske cannabinoider i hårprøver (18).

Det finnes to kjente cannabinoidreseptorer (CB1 og CB2) (19). CB1-reseptorene er lokalisert i sentrale og perifere nerveender. Aktivering av CB1-reseptorer forårsaker hevet stemningsleie, men kan også gi angst og panikk. Hukommelse, tidsoppfatning samt syns- og hørselsinntrykk påvirkes. CB2-reseptorer finnes først og fremst på immunceller, men også i sentralnervesystemet. CB2-reseptoragonister kan dempe betennelsesutløst smerte (19).

Mens THC bare kan gi delvis aktivering ved binding til CB1- og CB2-reseptorer (takeffekt), er syntetiske cannabinoider fullagonister og kan aktivere CB1-reseptorene maksimalt, og også ved betydelig lavere konsentrasjoner $(19,20)$.

Produkter med syntetiske cannabinoider inneholder ikke andre naturlige cannabinoider som finnes i cannabisplanten. Blant annet er det vist at cannabidiol fra naturlig cannabis gir redusert risiko for psykose (1). Enkelte syntetiske cannabinoidprodukter inneholder fettsyren oleamid, som aktiverer $\mathrm{CB} 1$-reseptorene og kan bidra til økt risiko for psykose $(21,22)$.

\section{Deteksjonsmetoder}

Man antar at brukerdosene er lave, i størrelsesorden 0,5-5 $\mathrm{mg}$. I noen tilfeller er det flere stoffer i blandingene, slik at mengden av hvert stoff blir svært lav. Analyser for disse stoffene må derfor ha tilstrekkelig sensitivitet. Urinanalyser vanskeliggjøres av at syntetiske cannabinoider raskt omdannes til 
et stort antall stort sett ukjente metabolitter. Flere ulike syntetiske cannabinoider omdannes til de samme metabolittene, slik at funn i urinprøve ikke entydig viser hvilket cannabinoid som er inntatt $(15,17,23)$.

Moderstoff fra cannabinoidene kan påvises i blod og spytt $(5,13,24)$. Ved Folkehelseinstituttet utføres kromatografiske analyser av syntetiske cannabinoider i blod- og spyttprøver som inneholder modersubstansen. Foreløpig kan 20 ulike syntetiske cannabinoider detekteres (25). Instituttet samarbeider med Tollvesenet og Kripos og vil ved opplysninger om nye varianter av syntetiske cannabinoider i norske beslag inkludere disse $\mathrm{i}$ analyserepertoaret.

Siden syntetiske cannabinoider, med unntak av de klassiske cannabinoidene, er strukturelt forskjellige fra THC, vil de fleste ikke påvises ved hurtigtester for cannabis $(21,22$, 26). Arbeidet med å fremstille immunologiske hurtigtester for syntetiske cannabinoider er påbegynt, men det kan ikke forventes at én enkelt test kan favne hele gruppen.

Effekter av syntetiske cannabinoider

Brukere oppga i en Internett-undersøkelse at syntetiske cannabinoider har en sterk cannabisliknende effekt (27). $87 \%$ rapporterte om positive effekter, mens $40 \%$ rapporterte om negative/uønskede effekter. Auwarter og medarbeidere (22) rapporterte om moderat beruselse, med endring av humør og persepsjon, etter røyking av et Spice-produkt. Rusfølelsen skal vare i under 30 minutter (28).

Man vet per i dag lite om effekter og skadelige virkninger av bruk av syntetiske cannabinoider - det gjelder både etter enkeltinntak og etter bruk over lengre tid. Tabell 1 $(22,26,28-43)$ viser effekter som er kasuistisk rapportert etter inntak av syntetiske cannabinoider. De fleste symptomene likner det man ser ved overdosering av cannabis, men også andre, mer alvorlige er rapportert, som kramper, uttalt hypokalemi, hypertensjon og koma. Det er flere rapporterte tilfeller hvor inntak har krevd sykehusbehandling (43). Det er beskrevet alvorlig kognitiv påvirkning og bevissthetstap $(31,32)$.

\section{Toleranse, avhengighet}

og abstinensreaksjoner

Man vet i dag lite om langtidseffektene ved bruk av syntetiske cannabinoider hos mennesker $(11,21,44)$. Kasuistisk er toleranseutviklingen for syntetiske cannabinoider rask (40). Hos rotter som ble gitt HU-210 over en lengre periode, er det sett redusert aktivering av CB1-reseptorer. Denne reduksjonen var doseavhengig (45).

Avhengighet er rapportert etter daglig bruk av høye doser syntetiske cannabinoider i flere måneder (40). I en Internett-basert undersøkelse oppfylte $37 \%$ av deltakerne kriteriene for misbruk og $12 \%$ avhengighetskriteriene i henhold til diagnosekodeverket DSM-IV (American Psychiatric Association, 2000) (27).

Tabell 1 Utilsiktede kliniske effekter rapportert ved bruk av syntetiske cannabinoider

\begin{tabular}{|c|c|c|}
\hline Organsystem & Symptomer & Referanse \\
\hline \multirow[t]{10}{*}{ Sentralnervesystemet } & Agitasjon/panikkanfall & $26,28-30$ \\
\hline & Tap av bevissthet/koma & 26,33 \\
\hline & Angst & 28,29 \\
\hline & Psykose & $29,41,42$ \\
\hline & Paranoia & 24 \\
\hline & Forvirring & 39,43 \\
\hline & Kramper & 31 \\
\hline & Irritasjon & 32 \\
\hline & Selvmordsforsøk & 33 \\
\hline & Endring i humør og persepsjon & 22 \\
\hline \multirow[t]{4}{*}{ Hjerte- og karsystemet } & Takykardi & $29,30,34$ \\
\hline & Hypertensjon & 26,35 \\
\hline & Brystsmerter & 36 \\
\hline & Kardial iskemi & 37 \\
\hline \multirow[t]{3}{*}{ Metabolismen } & Hyperglykemi & 38 \\
\hline & Hypokalemi & 39 \\
\hline & Acidose & 26 \\
\hline Mage-tarm-systemet & Kvalme/oppkast & $27,35,40$ \\
\hline \multirow[t]{2}{*}{ Det autonome nervesystem } & Feber & 30 \\
\hline & Mydriasis & 26 \\
\hline \multirow[t]{2}{*}{ Annet } & Dødsfall1 & \\
\hline & Selvmord ${ }^{1}$ & \\
\hline
\end{tabular}

Abstinenssymptomer er sjelden rapportert, men er sett etter hyppig bruk (27). Uttalt abstinens er beskrevet etter daglig bruk, og symptomene inkluderer hodepine, angst, nervøsitet, hoste, søvnforstyrrelse, irritabilitet, nedsatt konsentrasjon, kvalme, depresjon og rastløshet (40). Ved avrusning ble det rapportert økt svetting, sterk rustrang (craving), mareritt, tremor, hodepine, palpitasjoner, kvalme og oppkast (40).

\section{Intervensjon}

Behandling av akutte intoksikasjoner er symptomatisk. Ved milde og moderate symptomer kan monitorering og hydrering være tilstrekkelig. De som har symptomer på angst, panikkanfall og agitasjon etter bruk av syntetiske cannabinoider kan behandles med forsiktig bruk av benzodiazepiner $\mathrm{i}$ akuttfasen. Antipsykotisk medikasjon kan vurderes hos psykotiske (28).

\section{Lovlig status, endringer i markedet og overvåking}

I begynnelsen av 2009 ble syntetiske cannabinoider tatt inn under narkotikalovgivningen i flere land i Europa, men stadig nye ble produsert. Fra desember 2011 er åtte syntetiske cannabinoider oppført på den norske narkotikalisten, og det arbeides med å inkludere flere. Det er en stor utfordring å oppdatere lovverket i takt med produksjon/bruksmønsteret (fig 1).
EUs narkotikaovervåkingssenter (EMCDDA) har som hovedoppgave å overvåke situasjonen i Europa. Norge har vært medlem siden 2001. En viktig del av arbeidsoppgavene er identifisering og tidlig varsling om forekomst av nye narkotiske stoffer (early warning system) (46). Per i dag overvåkes 56 ulike syntetiske cannabinoider, 23 av disse ble inkludert i 2011.

\section{Konklusjon}

Et stort antall syntetiske cannabinoider selges via Internett som «herbal highs» og «legal highs». Et økende antall av disse stoffene påvises i norske beslag. Dette tyder på økende bruk. Bruk er assosiert med høyere risiko for alvorligere hendelser enn etter cannabisbruk. Stor variasjon i mengden psykoaktivt stoff i de ulike produktene gjør det vanskelig å forutsi effekter. Dette kan innebære høyere risiko for overdose enn ved cannabisbruk.

\section{Silja Skogstad Tuv (f. 1976)}

er konstituert overlege ved Divisjon for rettstoksikologi og rusmiddelforskning, Nasjonalt folkehelseinstitutt

Forfatter har fylt ut ICMJE-skjemaet og oppgir ingen interessekonflikter. 


\section{Maren Cecilie Strand (f. 1979)}

er konstituert overlege.

Forfatter har fylt ut ICMJE-skjemaet og oppgir

ingen interessekonflikter.

\section{Ritva Karinen (f. 1955)}

er m.sc. (fil.mag.) og forsker

Forfatter har fylt ut ICMJE-skjemaet og oppgir ingen interessekonflikter.

\section{Elisabeth Leere Øiestad (f. 1970)}

er dr.scient. og forsker

Forfatter har fylt ut ICMJE-skjemaet og oppgir ingen interessekonflikter.

\section{Asbjørg S. Christophersen (f. 1942}

er cand.pharm., dr.scient. i analytisk farmasi og forsker.

Forfatter har fylt ut ICMJE-skjemaet og oppgir ingen interessekonflikter.

\section{Vigdis Vindenes (f. 1974)}

er ph.d. og spesialist i klinisk farmakologi. Forfatter har fylt ut ICMJE-skjemaet og oppgir ingen interessekonflikter.

\section{Litteratur}

1. Fattore L, Fratta W. Beyond THC: the new generation of cannabinoid designer drugs. Front Behav Neurosci 2011; 5: 60

2. Vardakou I, Pistos C, Spiliopoulou Ch. Spice drugs as a new trend: mode of action, identification and legislation. Toxicol Lett 2010; 197: 157-62.

3. Hudson S, Ramsey J. The emergence and analysis of synthetic cannabinoids. Drug Test Anal 2011; 3: $466-78$

4. Narkotikalisten. www lovdata no/for/sf/ho/ to-19780630-0008-001.html (20.6.2012).

5. Dresen S, Kneisel S, Weinmann W et al. Development and validation of a liquid chromatographytandem mass spectrometry method for the quantitation of synthetic cannabinoids of the aminoalkylindole type and methanandamide in serum and its application to forensic samples. J Mass Spectrom 2011; 46: 163-71.

6. Ernst L Schiebel HM, Theuring $\mathrm{C}$ et al Identification and characterization of JWH-122 used as new ingredient in «Spice-like» herbal incenses. Forensic Sci Int 2011; 208: e31-5.

7. Nakajima J, Takahashi M, Seto T et al. Identification and quantitation of two benzoylindoles $\mathrm{AM}-694$ and (4-methoxyphenyl)(1-pentyl-1H-indol-3yl)methanone, and three cannabimimetic naphthoylindoles JWH-210, JWH-122, and JWH-019 as adulterants in illegal products obtained via the Internet. Forensic Toxicology 2011: 29: 95-110.

8. Kripos. Narkotikastatistikk 1. halvår 2011. www.politi.no/vedlegg/lokale_vedlegg/kripos/ Vedlegg_1371.pdf (15.8.2012)

9. Hu X, Primack BA, Barnett TE et al. College students and use of K2: an emerging drug of abuse in young persons. Subst Abuse Treat Prev Policy 2011; 6: 16

10. Grotenhermen F. Pharmacokinetics and pharmacodynamics of cannabinoids. Clin Pharmacokinet 2003; 42: 327-60.
11. EMCDDA. Understanding the 'Spice' phenomenon. www.emcdda.europa.eu/attachements.cfm/ att_80086_EN_Spice\%20Thematic \%20paper \%20 \%E2 \%80\%94\%20final \%20version.pdf (15.8.2012).

2. EMCDDA. Synthetic cannabinoids and 'Spice'. www.emcdda.europa.eu/publications/ drug-profiles/synthetic-cannabinoids (15.8.2012).

13. Teske J, Weller JP, Fieguth A et al. Sensitive and rapid quantification of the cannabinoid receptor agonist naphthalen-1-yl-(1-pentylindol-3-yl)methanone (JWH-018) in human serum by liquid chro matography-tandem mass spectrometry. J Chromatogr B Analyt Technol Biomed Life Sci 2010; 878: 2659-63

14. Coulter C, Garnier M, Moore C. Synthetic cannabinoids in oral fluid. J Anal Toxicol 2011; 35: 424-30.

15. Sobolevsky T, Prasolov I, Rodchenkov G. Detection of JWH-018 metabolites in smoking mixture postadministration urine. Forensic Sci Int 2010; 200: $141-7$

16. Chimalakonda KC, Moran CL, Kennedy PD et al. Solid-phase extraction and quantitative measurement of omega and omega-1 metabolites of JWH 018 and JWH-073 in human urine. Anal Chem 2011; 83: 6381-8

17. Hutter M, Broecker S, Kneisel S et al. Identification of the major urinary metabolites in man of seven synthetic cannabinoids of the aminoalkylindole type present as adulterants in 'herbal mixtures' using LC-MS/MS techniques. J Mass Spectrom 2012; 47: 54-65

18. Neukamm MA, Sachs H, Mürdter TE et al. Determination of 'Spice' cannabinoids in serum and hair by liquid chromatography-tandem mass spectometry. Toxichem Krimtech 2011; 78 (suppl): 219

19. Wintermeyer A, Möller I, Thevis M et al. In vitro phase I metabolism of the synthetic cannabimimetic JWH-018. Anal Bioanal Chem 2010; 398: 2141-53.

20. Showalter VM, Compton DR, Martin BR et al. Evaluation of binding in a transfected cell line expressing a peripheral cannabinoid receptor (CB2): identification of cannabinoid receptor subtype selective ligands. J Pharmacol Exp Ther 1996 278: $989-99$.

21. Dresen S, Ferreirós N, Pütz M et al. Monitoring of herbal mixtures potentially containing synthetic cannabinoids as psychoactive compounds. J Mass Spectrom 2010; 45: 1186-94

22. Auwärter V, Dresen S, Weinmann W et al. 'Spice' and other herbal blends: harmless incense or cannabinoid designer drugs? J Mass Spectrom 2009; 44: 832-7.

23. Chimalakonda KC, Bratton SM, Le VH et al. Conjugation of synthetic cannabinoids JWH-018 and JWH-073, metabolites by human UDP-glucuronosyltransferases. Drug Metab Dispos 2011; 39: 1967-76.

24. Kacinko SL, Xu A, Homan JW et al. Development and validation of a liquid chromatography-tandem mass spectrometry method for the identification and quantification of JWH-018, JWH-073, JWH019 , and JWH-250 in human whole blood. J Anal Toxicol 2011; 35: 386-93.

25. Øiestad EL, Johansen U, Karinen R et al. Determination of synthetic cannabinoids in oral fluid with ultra performance tandem mass spectrometry UPLC-MS/MS. Hamamatsu, Japan: International Association of Forensic Toxicologists (TIAFT), 2012

26. Simmons J, Cookman L, Kang $C$ et al. Three cases of «spice» exposure. Clin Toxicol (Phila) 2011; 49: $431-3$.

27. Vandrey R, Dunn KE, Fry JA et al. A survey study to characterize use of Spice products Isynthetic cannabinoids). Drug Alcohol Depend 2012: 120 238-41.

28. Castellanos D, Singh S, Thornton $G$ et al. Synthetic cannabinoid use: a case series of adolescents. J Adolesc Health 2011; 49: 347-9.

29. Schneir AB, Cullen J, Ly BT. «Spice» girls: synthetic cannabinoid intoxication. J Emerg Med 2011 40: $296-9$.

30. Lapoint J, James LP, Moran CL et al. Severe toxicity following synthetic cannabinoid ingestion. Clin Toxicol (Phila) 2011; 49: 760-4

31. Schneir AB, Baumbacher T. Convulsions associated with the use of a synthetic cannabinoid product. J Med Toxicol 2012; 8: 62-4.

32. Banerji S, Deutsch CM, Bronstein AC. Spice ain't so nice. Clin Toxicol 2010; 48: 632.

33. Missouri Department of Health \& Senior Services. $\mathrm{K} 2$ synthetic marijuana use among teenagers and young adults in Missouri. www.webcitation.org/ 66WpqHSpg (15.8.2012)

34. Simmons JR, Skinner CG, Williams J et al. Intoxication from smoking «spice». Ann Emerg Med 2011: 57: 187-8.

35. Donnelly MT. Health advisory: K2 synthetic marijuana use among teenagers and young adults in Missouri. http://health.mo.gov/emergencies/ert/ alertsadvisories/pdf/HAd3-5-2010.pdf (15.8.2012).

36. Young AC, Schwarz E, Medina G et al. Cardiotoxicity associated with the synthetic cannabinoid, K9 with laboratory confirmation. Am J Emerg Med 2012; 30: 1320.e5-7.

37. Mir A, Obafemi A, Young A et al. Myocardial infarc tion associated with use of the synthetic cannabinoid K2. Pediatrics 2011; 128: e1622-7.

38. Seely KA, Prather PL, James LP et al. Marijuanabased drugs: innovative therapeutics or designer drugs of abuse? Mol Interv 2011: 11: 36-51.

39. Vearrier D, Osterhoudt KC. A teenager with agitation: higher than she should have climbed. Pediatr Emerg Care 2010; 26: 462-5.

40. Zimmermann US, Winkelmann PR, Pilhatsch M et al. Withdrawal phenomena and dependence syndrome after the consumption of «spice gold». Dtsch Arztebl Int 2009; 106: 464-7.

41. Müller H, Sperling W, Köhrmann M et al. The synthetic cannabinoid Spice as a trigger for an acute exacerbation of cannabis induced recurrent psychotic episodes. Schizophr Res 2010; 118: 309-10.

42. Every-Palmer S. Warning: legal synthetic cannabinoid-receptor agonists such as JWH-018 may precipitate psychosis in vulnerable individuals. Addiction 2010; 105: 1859-60

43. Ernst L, Schiebel HM, Theuring $C$ et al. Identification and characterization of JWH-122 used as new ingredient in «Spice-like» herbal incenses. Forensic Sci Int 2011: 208: e31-5.

44. Griffiths P. Sedefov R, Gallegos A et al. How globalization and market innovation challenge how we think about and respond to drug use: 'Spice' a case study. Addiction 2010; 105: 951-3.

45. Dalton VS, Zavitsanou K. Cannabinoid effects on $\mathrm{CB} 1$ receptor density in the adolescent brain: an autoradiographic study using the synthetic cannabinoid HU210. Synapse 2010; 64: 845-54.

46. Pscyhonaut Web Mapping Research Group. Spice Report. www.psychonautproject.eu/documents/ reports/Spice.pdf (15.8.2012).

Mottatt 17.4. 2012, første revisjon innsendt 21.5 2012, godkjent 16.8. 2012. Medisinsk redaktør Kristin Viste. 